\title{
A Study on Determinants of Voluntary Tax Compliance in Bahir Dar, Ethiopia
}

\author{
Abate Gashaw Ayele \\ Lecturer, College of Business and Economics, Debre Markos University \\ PO.Box 269, Debre Markos, Ethiopia \\ Yitayish Tesfa Bitew \\ Principal, Yitayish Tesfa Certified Audit Firm, Bahir Dar, Ethiopia
}

\begin{abstract}
In Ethiopia, as in some other developing countries, tax noncompliance is a serious challenge facing income tax administration and hindering tax revenue performance. Hence, this study focused on the relationship between the perceptions of equity/fairness, strength of tax authority, lack of ability to pay, perceptions of government spending, enforcement of tax law, tax knowledge, complexity of tax system, and compliance costs are investigated to examine the effect of these independent variables on dependent variable (income tax compliance) in Bahir Dar City Administration of Amhara National Regional State taxpayers. Quantitative research design is used, primary data are collected using structured questionnaire from a sample of 125 taxpayers of the city dwellers, selected using purposive and random sampling. For data analysis descriptive statistics, correlation, and regression analysis techniques are employed. The result of the study indicated that perceptions of equity/fairness, lack of ability to pay, Perceptions of government spending, tax knowledge, complexity of tax system, and compliance costs have a direct and significant effect on income tax compliance while organizational strength of tax authorities and appropriate enforcement of tax law have a direct but insignificant effect on income tax compliance. Out of these variables lack of ability to pay, compliance costs and complexity of the tax system are related negatively with the income tax compliance. Considering the findings of the study, maintaining tax fairness and equity, building capacity of the tax authority, conducting extensive awareness creation programs, and providing social services to the general public is suggested.
\end{abstract}

Keywords:Tax compliance, perceptions of fairness, ability to pay, government spending, tax knowledge, complexity of tax system, and compliance costs.

DOI: $10.7176 /$ RJFA/10-23-04

Publication date: December $31^{\text {st }} 2019$

\section{Introduction}

\subsection{Background of the study}

In many under developed countries like Ethiopia, the low revenue yield of taxation can only be attributed to the fact that the tax provisions are not properly enforced, either on account of the inability of the administration to cope with them, or on account of straight forward corruption. But factors on the other side of the system get little attention, i.e. minor attention is given to the cultural background of tax payers, their awareness level, compliance behavior and its determinants when designing a given tax system.

For voluntary system to work successfully, the people must be confident that the taxes are levied fairly and that everyone pays his share. If the feeling becomes widespread that the tax system is a collection of loopholes and evasions, if people see their equally prosperous neighbors paying substantially less or enjoying tax- free expense account living, taxpayer morale declines. Once this attitude prevailed in the public it is difficult to rectify it and costs the authorities a huge compliance and collection costs. Eckstein (1979) stated that the tax system must be fair, both to promote the objective of an equitable distribution of income and to assure continued voluntary compliance by the taxpayer.

Hence, this study aims to identify factors that affect the tax payer's voluntary compliance i.e. what factors motivate taxpayers to comply with the tax system or what factors influence tax payers not to comply with tax system by taking EMR Bahir Dar Branch taxpayers in to account. The output of this study helps the tax authority to incorporate measures that address these pitfalls while designing a tax system or policy.

\subsection{Statement of the problem}

The definition of compliance is usually cast in terms of the degree to which tax payers comply with tax law. The degree of non-compliance can be measured in terms of the 'tax gap'. This represents the difference between actual revenue and that would be received if there were 100\% compliance (James, S. and Nobes, C., 2000).

In Ethiopia, as in some other developing countries, tax noncompliance is a serious challenge facing income tax administration and hindering tax revenue performance. Despite the various tax reforms undertaken by Ethiopian government to increase tax revenue over the years, prior statistical evidence has proven that the 
contribution of income taxes to the government's total revenue remained low. The tax revenues as percentage of GDP in the year 2017 in Ethiopia is 6.6\% which is less than other African countries like, South Africa $26.3 \%$, Malawi 18.8\%, Tanzania 14.8\%, Uganda 11.9\% (IMF, 2010).

This low contribution may be a manifestation of different factors so the factors which affect compliance are important.

Voluntary compliance is a function of taxpayers' attitude towards taxation and organizational strength (efficiency and effectiveness) of the tax administration in the tax authority. Taxpayers' attitude towards taxation is also in turn affected by the social, cultural, and political factors as well as awareness about tax and fairness of the tax system.

Even though Ethiopian modern tax administration is not older than half a century, it has undergone several legal amendments during this time.

For example, the income tax proclamation no. 286/2002 has increased the amount of penalties and strengthened the means of enforcement while it states nothing about how to create and increase the awareness of the taxpayers. But the improvement is not as big as its age as far as citizen's voluntary compliance is concerned. It implies that relying solely on legal enforcement (stick approach) may not work always and forever. Rather, in addition to enforcement, the authority must follow a participatory and holistic approach in addressing the issue of voluntary compliance

Understanding the factors that determine the compliance and non- compliance behavior of taxpayers with tax laws is a key to further motivating and assisting the compliers and designing appropriate strategies to deal with non-compliers. As there is no empirical study which uncovers the determinants of taxpayers' voluntary compliance in the study area, this study is undertaken to assess and investigate the determinants of taxpayers' on voluntary compliance of tax in Ethiopian Ministry of Revenue (EMR) Bahir Dar branch. Hence, to address the issue, the following questions are formulated.

- To what extent the business communities know the income tax rules and regulations?

- What are the variables that affect the taxpayers' voluntary compliance behavior?

- What factors make the taxpayers non-compliers?

- How strong enough is the tax authority to administer those noncompliance and delinquent tax payers?

\subsection{Objectives of the study}

The main objective of this study is to assess the factors which affects the voluntary compliance of tax payers' on income tax in EMR Bahir Dar Branch.

The specific objectives of the study are:-

$>$ To assess if the taxpayers have sufficient knowledge about the tax rules and regulations

$>$ To identify the determinants of taxpayers' voluntary compliance;

$>$ To examine the factors which make the taxpayers not to comply with tax law;

$>$ To identify the main problems of tax administration practices in EMR Bahir Dar Branch

\subsection{Research Hypothesis}

In line with the objectives of the study and research questions, the following hypotheses are formulated:

H1: There is a positive relationship between in tax compliance and perception of equity/fairness.

$\mathrm{H} 2$ : There is a positive relationship between tax compliance and organizational strength of tax authorities.

H3: There is a negative relationship between income tax compliance and lack of ability to pay.

H4: There is a positive relationship between tax compliance \& perceived enforcement of tax law.

H5: There is a positive relationship between income tax compliance and tax knowledge.

H6. There is a negative relationship between income tax compliance and Tax Rate.

H7. There is a negative relationship between tax compliance and Complexity of the Tax System.

\subsection{Significance of the study}

The main outcome of this study is identifying the determinant factors for tax payers non-compliant. Thus the findings of the study may offer the tax authority to design \& redesign the tax administration system that will use to reduce tax non-compliant and to promote better tax system and to increase tax revenue. Other researchers can also use it as reference point in further research in the area of tax administration.

\subsection{Scope of the study}

This study assesses and analyses the tax administration system and factors that determine the voluntary compliance of income tax with special reference of EMR Bahir Dar Branch tax payers.

\section{Literature Review}

Government needs financial resources to act as a government and play a role that is expected from it by the 
public (Lymer and Oats, 2009). So what the government gives it must first take away. The economic resources available to society are limited, and so an increase in government expenditure normally means a reduction in private spending. In this regard James, S. and Nobes, C. (2000) states that taxation is one method of transferring resources from the private to the public sector. Therefore, tax is an instrument that stabilizes the economy, and reduces private demand so that resources can be released for public sector use.

Countries whether they are developing or developed, levy taxes to raise funds in order to cover public expenditures and to properly allocate resources. Whatever its function and essence, tax is fundamentally important for the existence of a government and a nation. Hence, the taxes that governments levy have to be governed by certain principles.

\subsection{The Concept and Definition of Tax Compliance and Noncompliance}

Tax compliance is expressed in terms of the degree to which taxpayers comply with tax law or the degree to which a taxpayer obliges to tax rules and regulations and the degree of noncompliance is measured in terms of the tax gap, which is the difference between the taxes that the law seeks to collect and those in fact collected. This gap happens by means of both tax avoidance and tax evasion. Similarly, compliance gap is also the break between the actual and the potential tax revenue and how that gap varies among the different sectors of the taxpaying population. Different authors define voluntary tax compliance in different ways. For instances, James and Alley (2004) define voluntary tax compliance as:-“...the willingness of individual and other taxable entities to act in accordance within the spirit as well as the tax law and administration without the application of enforcement activity".

According to Kirchler (2007) compliance classified in to voluntary and enforced compliance. Voluntary compliance is made possible by the trust and cooperation ensuing between tax authority and taxpayer and it is the willingness of the taxpayer on his own to comply with tax authority's directives and regulations.

Organization for Economic Cooperation and Development (OECD, 2001) categorized tax compliance into administrative compliance and technical compliance. Administrative compliance is made up of reporting compliance, procedural compliance and regulatory compliance and it is generally concerned with complying with the rule relating to lodging and payment of tax while technical compliance is concerned with meeting up technical requirement of tax laws in computation of tax liability.

Non-compliance is also perceived as the failure of a taxpayer to report (correctly) the actual income, claim deductions and rebates and remit the actual amount of tax payable to the tax authority on time (Kirchler, 2007). Some studies also segmented income tax non-compliance into unintentional and intentional behavior (Loo, 2006).

Noncompliance with tax laws comes in different forms. It may be intentional noncompliance in which the taxpayer deliberately undermines the tax rules and regulations for his/her personal gains. The second is in form of unintentional noncompliance, which may be as result of ignorance, oversight or mistake in applying tax laws. Any noncompliance act committed by taxpayer which results to non-declaration or underreporting of taxable income leading to non-payment or underpayment of tax is regarded as tax evasion.

Tax noncompliance is the failure of taxpayer to meet tax obligations whether the act is done intentionally or unintentionally (James \& Alley, 2004). However, Kirchler (2007) argued that since degree of compliance varies then certain noncompliance might not violate the law. Soos (1991) broadly classified noncompliance into four types failing to file a tax return; underreporting of taxable income; overstating tax claims such as exemptions, expenses etc and failing to make timely payment of tax liability.

\subsection{Determinants of taxpayers' on voluntary tax compliance behavior}

The problem of tax non-compliance is as old as taxes themselves. Characterizing and explaining the observed patterns of tax non-compliance, and ultimately finding ways to reduce it, are of obvious importance to nations around the world.

Generally, the determinant factor on voluntary tax compliance of taxpayers' comes broadly from two sources. These are:-

A. From tax administration problems of the authority and

B. From the side of taxpayers attitude towards taxation.

A. Tax Administration

The goal of tax administration is to foster voluntary tax compliance (Silvani, 1992) and hence reduce tax gap (difference between taxes paid and owed for all taxes by all taxpayers) and compliance gap. This can be done through assessment of potential taxpayers, identifying and registering the tax payers and provision of tax payer services among others. The tax authority frequently assesses tax returns submitted by tax payers. These assessments are typically desk reviews of self-declarations and supporting documents. The tax officer may accept the tax payers' declaration as it is or assesses an additional tax to be paid. Proclamation 286/2002 has been able to further strengthen tax administration through a series of institutional reforms. Tax authority 
administers different types of taxes under different Laws (Acts) such as income tax, value added tax, customs duties and excise tax are among many others. Hence tax authority is supposed to ensure taxpayers comply with the respective tax law.

Regardless of how carefully tax laws have been made, they could not eliminate conflict between tax administration and tax payers. It is generally known that tax laws and tax policy are as good as the tax administration. Therefore, without the permanent reorganization of the tax administration and the daily improvements in methods of its management, it is impossible to expect that tax reforms could be realized successfully.

B. Tax payers' attitude

Attitude may be defined as positive or negative views of an object i.e. a person, behavior or event. In relation to taxation, taxpayers' attitudes may be defined as positive or negative views of tax compliance behavior. The outcome of positive views is tax compliance and negative view is tax noncompliance. These views may be explained by psychology-based theories which reveal that taxpayers' attitude may be influenced by the following factors which eventually influence taxpayers' behavior. Tax payers' perceptions in the tax system affect commitments in paying taxes. The commitment reflects beliefs about the desirability of the tax systems and feelings of moral obligation to act in the interest of the collective and pay one's tax with goodwill.

Having the above two broad determinant factors, the voluntary tax compliance is influenced by a host of many separate factors like the equity/fairness, strength of tax authority, lack of ability to pay, tax knowledge, enforcement of tax law, tax rate, complexity of tax system and so on.

\subsection{The conceptual Framework}

The conceptual Framework is adopted from existing literature. The model explains the relationship between perceptions of equity/fairness, strength of tax authority, lack of ability to pay, enforcement of tax law, tax knowledge, Tax rate, and complexity of tax system (as independent variables) and income tax compliance (as dependent variable). It has been reflected in the works of (Zelalem B., 2011; Annet N., 2010; Gloria M., 2011; Mohd R. P., 2011; Lemessa T., 2007) with changes to fit different countries' tax system. The following conceptual Framework was used to guide the study.

Fig 2.1: The conceptual Framework Model

\section{The independent variables \& the dependent variable}

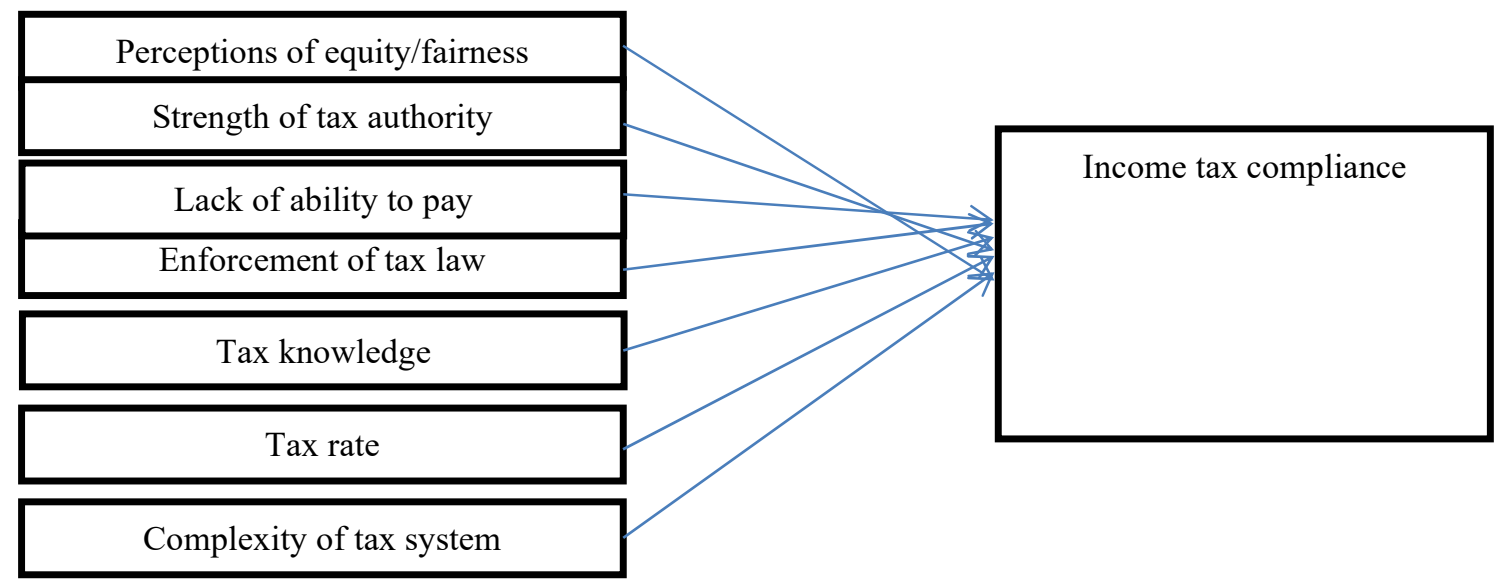

Source: Adopted from Mohd R.P. (2010)

\section{Research Methodology}

\subsection{Research Design}

The research design employed in this study is quantitative nature of the survey type and it attempted to examine the various determinant factors (independent variables) that can affect the voluntary compliance of income tax (dependent variable) in EMR Bahir Dar Branch. We used correlation and regression approaches to investigate the relationships between the variables of the study in a causal system by avoiding bias, summarization of large information and testability of the hypothesis. This is because the objective is to examine the relationship between these variables.

\subsection{Population, Sample size and Sampling Design}

The accessible population of the study comprises of all licensed business tax payers EMR Bahir Dar Branch. The number of tax payers who were registered until (2019) is 1,138 (EMR, Bahir Dar Branch). We use random sampling to select which tax payers will be chosen. Having this, the sample size is determined based on the Taro 
Yamane (1966) formula stated bellow as:

$n=N /\left(1+N x(e)^{2}\right)$

Where;

- $\mathbf{N}$ is the accessible population,

- $\quad \boldsymbol{n}$ is the sample size and

- $e$ is the error coefficient (since the population is too large, the researcher take e as $8 \%$ )

Based on the above formula the number of the sample $(n)$ to be considered is calculated as follows:

$n=N /\left(1+\left(N x(e)^{2}\right)\right)$

$n=1,138 /\left(1+\left(1,138(0.08)^{2}\right)\right)$

$n=\underline{\underline{137}}$

Then sample size includes 137 licensed business tax payers. Tax payers are randomly drawn from 1,138 taxpayers. The researchers use this random sampling method because it is more reliable, valid, as well as each individual (respondents) has an equal probability of being selected and the sample can be generalized to the larger population.

\subsection{Data type and Sources}

In order to gather relevant information, possible methods will be selected, that are both primary and secondary data.

\subsection{Measurement of Variables}

A five (5) point Likert scales data measurement is used in this research. Because it allows the respondents to indicate their attitudes by checking how strongly they agree or disagree with the constructed statements to measure the assumed variable under the study. Five alternatives are used in this research: strongly disagree, disagree, neutral, agree, and strongly agree respectively representing one to five.

\subsection{Data Collection Instruments}

Primary data were obtained from the selected tax payers of EMR Bahir Dar Branch using self-administered questionnaires, being as the best data collecting tool. This is so because questionnaire is the least expensive, time saving and encourages the respondents to fill their feeling, which consisting of close ended questions.

\subsection{Validity of instruments}

The validity of the study instruments is performed using the content validity index (CVI) on a four point scale of relevant (4), quite relevant (3), somewhat relevant (2) and not relevant (1). The researchers also distributed the questionnaires to 15 experts to rate the relevance of questions.

\subsection{Reliability of the instrument}

To ensure accuracy, consistency and completeness, researchers have given the questionnaires to 20 taxpayers and collected these data from the respondents. Having done this, the researchers performed cronbach's alpha tests on the likert scales in the instrument for independent variables and tax compliance among taxpayers as shown in the table below:

Table 3.1: Reliability Test

Variables Cronbach's alpha Value

Perceptions of equity/fairness $\quad 0.712$

Strength of tax authority $\quad 0.735$

Lack of ability to pay $\quad 0.801$

Enforcement of tax law $\quad 0.778$

Tax knowledge $\quad 0.825$

Tax rate $\quad 0.845$

Complexity of tax system $\quad 0.768$

Tax compliance 0.786

The table 3.1 above shows alpha coefficient range between 0.712 and 0.845 for all scales and this suggest a satisfactory degree of internal consistency for all the metric.

\subsection{Data Processing, Analysis and Presentation}

Then data are analyzed using statistical package for social science (SPSS) program which provide descriptive outputs. Correlation analysis tools are carried out to establish the strength of the relationship between variables. Multiple regression analysis also used to determine how the predictor variables could explain the dependent variable. 
Ordinary Least Square (OLS) Model

ITC $i=+\beta 1$ PE $i+\beta 2$ STAi $+\beta 3 \mathrm{LAPi}+\beta 4 \mathrm{ETLi}+\beta 5 \mathrm{TKi}+\beta 6 \mathrm{TRi}+\beta 7 \mathrm{CTSi}+\mathrm{ei}$

Where:

ITCi-Income tax compliance

PEi-Perceptions of equity/fairness

STAi-Strength of tax authority

LAPi-Lack of ability to pay

ETLi- Enforcement of tax law

TKi- Tax knowledge

TRi- Tax rate

CTSi- complexity of tax system

- the constant value of the regression,

$\beta 1-7$ - the intercept of the regression respectively, and

ei - the random term.

\section{Data Analysis and Discussion of Results}

This chapter contains the results and the interpretation of the responses from the field. The beginning sub-section presents summary statistics of respondents who participated in the study. The second sub-section focuses on presenting the data results, especially the results from descriptive statistics which tries to give a general impression of values on individual variables and their components.

\subsection{Characteristics of respondents based on sex and age}

The following table analyses the characteristics of respondents based on sex and age.

Table 4.1. Distribution of respondents based on sex and age

\begin{tabular}{|c|l|c|c|}
\hline Indicator & Description & Number of respondents & Percentage \\
\hline \multirow{5}{*}{ Sex } & Male & 94 & 78.4 \\
\cline { 2 - 4 } & Female & 24 & 21.6 \\
\cline { 2 - 4 } & Total & 118 & 100.0 \\
\hline \multirow{5}{*}{ Age } & Below 35 years & 45 & 38.1 \\
\cline { 2 - 4 } & $35-50$ years & 50 & 42.4 \\
\cline { 2 - 4 } & Above 50 years & 23 & 19.5 \\
\cline { 2 - 4 } & Total & 118 & 100.0 \\
\hline
\end{tabular}

Source: Field survey (2019)

As depicted in table 4.1, majority of the respondents $94(76.4 \%)$ are male and $50(42.4 \%)$ of the total respondents range in the age of 35-50 years which is followed by $45(38.1 \%)$ of respondents that below 35 years.

\subsection{Educational Background}

Table 4.2. Distribution of Respondents based on educational level.

\begin{tabular}{|c|c|c|c|}
\hline Indicators & Description & Frequency & Percent \\
\hline \multirow{6}{*}{ Level of education } & Primary \& below & 13 & 11.0 \\
\hline & Secondary & 34 & 28.8 \\
\hline & Diploma & 40 & 33.9 \\
\hline & Degree & 25 & 21.2 \\
\hline & Masters \& above & 6 & 5.1 \\
\hline & Total & 118 & 100.0 \\
\hline
\end{tabular}

Source: Field survey (2019)

As shown in table 4.2 above, majorities of the respondents $40(33.9 \%)$ are Diploma graduated and 34 $(28.8 \%)$ have secondary level of education. 


\subsection{Business type}

Table 4.3. Distribution of Respondents based on Business type.

\begin{tabular}{|l|l|r|r|}
\hline Indicators & Descriptive & Frequency & \multicolumn{2}{|c|}{ Percent } \\
\hline & merchandise & 71 & 60.1 \\
Business type & Manufacturing & 12 & 10.2 \\
& service & 35 & 29.7 \\
& Total & 118 & 100.0 \\
\hline
\end{tabular}

Source: Field survey (2019)

As shown in table 4.3 above, majority of the respondents $71(60.2 \%)$ run merchandise business type and the rest $35(29.7 \%)$ service business \& $12(10.2 \%)$ manufacturing business.

\subsection{Descriptive Statistics}

The respondents were asked to indicate their extent of agreement or disagreement with some statements relating to some of the factors that influence taxpayers' view on voluntary income tax compliance in the branch. To analyze the results the degree of agreement or disagreement of the respondents for each statement are also analyzed by summarizing the five point likert scale responses in to three by considering the strongly agree and agree into one positive response (i.e. Agree) and the strongly disagree and disagree responses in to one negative responses (i.e. Disagree) and the neutral responses is taken as it is.

The respondents were asked to raise their views on the tax system in the branch and from the research data, as shown by table $4.4,57.46 \%$ of the respondents indicated that the tax system is unfair, as $36.44 \%$ and $6.1 \%$ indicated that it is a fair and neutral tax system respectively.

Some respondents disagreed that they are considering the concerns of average citizen when making decisions and the taxation system is fair, friendly \& conducive. While some respondents were agreeable with the paying of their fair/equity share of tax even if there is negative perception of equity and fairness. Some respondents were also slightly neutral with the service the EMR provides. It ensures that the perception of equity $\&$ fairness of the tax payers are slightly disagreeable in the part of the respondents.

According to the respondents' views on the organizational strength of tax authorities, as shown by table 4.4; $66.1 \%$ of the respondents indicated that the organizational strength of tax authorities is weak, $29.15 \%$ strong and the rest $4.75 \%$ indicated that it is neutral. The table also displays that the extent of organizational strength of tax authorities and its effect on tax compliance behavior revealed as most respondents disagreed that the probability of being audited affect my decision to under report the income; getting frequent training by tax authority. While some respondents were slightly neutral with the authority has adequate number of skilled and professional man power; tax system, assessment, and procedures are well organized; while some respondents were slightly agreeable the tax collection offices strategically located near to the taxpayers' work place.

Tax authority is the responsible body for assessing and collecting tax revenue. The amount of revenue collected is directly dependent on the efficiency and effectiveness of the authority. In light of this fact the survey result showed the tax authority of the branch is not efficient and effective in various aspects such as improving the tax assessment and collection procedures, creating awareness, providing services and information regarding tax. Hence, the poor effort of the tax authority in these area can be cited as the major factor that has contributed to the underlying problem and so that they are responsible for poor income tax compliance.

The respondents' views on the ability to pay, as shown below, $52.37 \%$ of the respondents indicated that the tax they pay is based on their ability to pay, $43.56 \%$ is not based on their ability to pay while the rest $4.07 \%$ indicated that it is neutral. Results revealed that most respondents disagreed that the tax they are paying is not based on their ability pay, assessment of income tax is not based on my capacity to pay .Some respondents were indifferent that means agreed on the priority between the debts and basic needs rather than the income tax; the effect of financial position on completing tax return; the reason for not paying tax obligation is because it is beyond their ability and have no sufficient disposable income; Therefore, when taxpayers have no enough disposable income and they used to consume the return from sales, it is clear that there would be poor income tax compliance.

The results on table 4.6 indicated that, $39.93 \%$ of the respondents are agreed on appropriate enforcement of tax law in order to comply with income tax while $55.55 \%$ is not agreed and the rest $4.52 \%$ is neutral. Results also revealed that if there is no penalty or legal enforcement, the possibility that they may not pay a tax would be increased; they receive the right penalty for the crime they have committed; there is late filing of tax return and over claiming deductions. Some respondents paying of taxes to avoid disturbances that come from the severity of sanctions and penalties; not filing a tax return; under reporting income; late tax payments; and the penalty rates are very low and be afford to pay the penalty. Therefore, if the enforcement of tax law is strengthening, income tax compliance would be increased.

With regard to the extent of tax knowledge and its effect on tax compliance behavior, which the 
respondents feel that they have limited knowledge, the results indicated that, $66.32 \%$ of the respondents have no tax knowledge in order to comply with income tax while $14.62 \%$ of them said that they are familiar on income tax laws and regulations and the rest $19.06 \%$ is neutral. Most respondents disagreed that they are familiar with income tax laws, proclamations and regulations, and attended educational sessions about taxation. While some respondents were in different with keep up to date transaction records and books of accounts for each year as well as they are accurately determine their tax liability by their own or by the help of other experts. Awareness is a corner stone as far as voluntary compliance is concerned. The survey data has shown that majority of the taxpayers have no detail knowledge about taxation. But, lack of awareness is the major and leading reason for tax evasion and avoidance. Hence the limited knowledge in the area of taxation can be cited as the factor that has contributed to the poor income tax compliance. Meaning, lack of or inadequate education could be seen as an important factor to income tax non-compliance.

The respondents' views on tax rate, as shown below, $51.69 \%$ of them indicated that the tax rate and amount is high, while $37.28 \%$ indicate that it is low, and the rest $11.02 \%$ indicated that it is neutral. Some respondents were indifferent with respect to tax rate are not high. Hence, as the tax rate and amount increases, leads to noncompliance income tax.

The complexity of the tax system and its effect on tax compliance behavior, the results indicated that, $81.99 \%$ of the respondents said that the tax system is complex in order to comply with income tax while $16.95 \%$ of them said that it is simple and the rest $2.33 \%$ said it is neutral. Most respondents disagreed that the tax system is well designed and it is easy to understand i.e. rate of tax, filing and paying dates; there are no loopholes in the tax system; and the tax office consults the community when there is a change in the tax system. Some respondents were indifferent for only one question i.e. the legislation and administrative procedures of income tax is simple.

The income tax compliance, which the respondents feel, is weak. The results indicated that, $73.22 \%$ of the respondents said that they have not paid their income tax obligation while $16.95 \%$ of them said that they were comply with tax law and the rest $9.83 \%$ said it is neutral. Most respondents also disagreed that their payment of income taxes on time; payment of EMR bills first before any other bills; and do not have outstanding debt with EMR. Some respondents were also slight different with the payment of the actual tax amount assessed; and never attempted to avoid tax.

Table 4.4: Descriptive statistics of the Variables

\begin{tabular}{|l|l|l|l|l|l|l|l|l|}
\hline Variables & $\begin{array}{l}\text { No. } \\
\text { Items }\end{array}$ & $\begin{array}{l}\text { strongly } \\
\text { disagree }\end{array}$ & disagree & neutral & Agree & $\begin{array}{l}\text { Strongly } \\
\text { agree }\end{array}$ & Mean & $\begin{array}{l}\text { St. } \\
\text { Deviations }\end{array}$ \\
\hline $\begin{array}{l}\text { Perceptions of } \\
\text { equity/fairness }\end{array}$ & 5 & $29.49 \%$ & $27.97 \%$ & $6.1 \%$ & $32.71 \%$ & $3.73 \%$ & 2.53 & 1.67 \\
\hline $\begin{array}{l}\text { Strength of tax } \\
\text { authority }\end{array}$ & 5 & $28.31 \%$ & $37.8 \%$ & $4.75 \%$ & $23.73 \%$ & $5.42 \%$ & 2.4 & 1.071 \\
\hline $\begin{array}{l}\text { Lack of ability to } \\
\text { pay }\end{array}$ & 5 & $25.42 \%$ & $26.95 \%$ & $4.07 \%$ & $31.19 \%$ & $12.37 \%$ & 2.78 & 1.35 \\
\hline $\begin{array}{l}\text { Enforcement of tax } \\
\text { law }\end{array}$ & 9 & $34.27 \%$ & $21.28 \%$ & $4.52 \%$ & $35.59 \%$ & $4.33 \%$ & 2.66 & 1.29 \\
\hline Tax knowledge & 4 & $20.13 \%$ & $46.19 \%$ & $19.07 \%$ & $14.62 \%$ & $0 \%$ & 2.28 & 0.918 \\
\hline Tax Rate & 3 & $20.9 \%$ & $16.38 \%$ & $11.02 \%$ & $48.02 \%$ & $3.67 \%$ & 2.97 & 1.21 \\
\hline $\begin{array}{l}\text { complexity of tax } \\
\text { system }\end{array}$ & 4 & $28.81 \%$ & $53.18 \%$ & $2.33 \%$ & $9.32 \%$ & $6.36 \%$ & 2.11 & .902 \\
\hline Tax compliance & 5 & $37.12 \%$ & $36.1 \%$ & $9.83 \%$ & $16.10 \%$ & $0.85 \%$ & 2.07 & 1.052 \\
\hline
\end{tabular}

Source: SPSS result based on samples respondent response data (2019)

\subsection{Correlation Analysis}

The Pearson's correlation coefficient (r) was run to determine the relationship between the variables. The correlation result is shown below: 
Table 4.5: Pearson's Correlation Matrixes

\begin{tabular}{|c|c|c|c|c|c|c|c|c|}
\hline & 1 & 2 & 3 & 4 & 5 & 6 & 7 & 8 \\
\hline Percep.of equity/ fairness & 1 & & & & & & & \\
\hline Orga.strength of tax authority 2 & .025 & 1 & & & & & & \\
\hline Lack of ability to pay & .109 & .011 & 1 & & & & & \\
\hline App. enforcement of tax law 4 & -.151 & .025 & -.177 & 1 & & & & \\
\hline Tax knowledge & -.044 & -.127 & -.060 & -.010 & 1 & & & \\
\hline Tax rate & .133 & -.130 & -.027 & .016 & $.186^{*}$ & 1 & & \\
\hline Complexity of the tax system. 7 & $-.183^{*}$ & -.057 & -.089 & .043 & -.013 & .054 & 1 & \\
\hline Income tax compliance 8 & $.229^{*}$ & $.222^{*}$ & $-.217^{*}$ & $.214^{*}$ & $.313^{* *}$ & -.116 & $-.255^{* *}$ & \\
\hline
\end{tabular}

**. Correlation is significant at the 0.01 level (2-tailed).

*. Correlation is significant at the 0.05 level (2-tailed).

a) The relationship between perceptions of equity/fairness and income tax compliance

The results in the table 4.5 shown above is that there is a significant positive relationship between perceptions of equity or fairness and income tax compliance $\left(\mathrm{r}=.229^{*}, \mathrm{p}<0.05\right)$. Therefore, when the perception of equity/fairness improves, tax compliance also increases and vice versa. This means that taxpayers are more compliance if the tax authority treats them equally and the perception of equity/fairness outstretch to all taxpayers. For instance, if the taxation system is fair, friendly and conducive, and everyone pays as well as the tax office considers the concerns of average citizens when making decisions; they are bound to pay their EMR bills first before any other bills.

b) The relationship between organizational strength and income tax compliance

The results in the table 4.5 shown above is that there is a significant positive relationship between organizational strength of tax authorities and income tax compliance $\left(r=.222^{*}, p<0.05\right)$. Therefore, when the organizational strength of tax authorities improves, tax compliance also increases and vice versa. This means that taxpayers are more comply with income tax if the organizational strength of tax authority is increasing. For instance, if the authority has adequate number of and skilled man power, and they are professional in the way they treat taxpayers as well as increasing audit coverage by auditing taxpayers' book of accounts, they are bound to pay their IRA bills on time and consequently not attempted to evasion and avoidance of taxation.

c) The relationship between lack of ability to pay and income tax compliance

As shown above in table 4.5, there is a significant negative relationship between lack of ability to pay and income tax compliance $\left(\mathrm{r}=-.217^{* *}, \mathrm{p}<0.05\right)$. Therefore, when the personal financial constraint increases, tax compliance decreases and vice versa. This means that taxpayers are more comply with income tax if taxpayers have the ability to pay or decrease the financial constraints. For instance, if the tax payers have faced financial constraints as well as have no sufficient disposable income for the time being, they are not bound to pay their EMR bills on time and consequently attempted to evasion and avoidance of taxation.

d) The relationship between enforcement of tax law and income tax compliance

The results in the table 4.7 shown above is that there is a significant positive relationship between the perceived enforcement of tax law and the income tax compliance $\left(\mathrm{r}=.214^{*}, \mathrm{p}<0.05\right)$. This implies if there is an enforcement tool for the tax law in place there will be an increase in tax compliance and vice versa. For instance, if the severity of sanctions and penalty rate is too high, taxpayers are bound to pay their EMR bills on time and consequently not attempted to evasion and avoidance of taxation.

e) The relationship between tax knowledge and tax compliance

The results in the table 4.5 above show that there is a significant positive relationship between tax knowledge and income tax compliance $\left(\mathrm{r}=.313^{* *}, \mathrm{p}<0.01\right)$. This means that taxpayers are more compliance if they have required tax knowledge. For instance, if taxpayers have the basic academic qualification coupled with some formal knowledge in taxation and are aware of most income tax laws, proclamations, regulations and guidelines about taxation of incomes, they are bound to pay their EMR bills first before any other bills and consequently not have any outstanding bills with the institution.

f) The relationship between tax rate and tax compliance

The results in the table 4.5 shown above is that there is insignificant but negative relationship between tax rate and income tax compliance $(\mathrm{r}=-.116)$. Even if tax rate relationship with tax compliance is insignificance, there is negatively related.

g) The relationship between complexity of the tax system and tax compliance

The results in the table 4.5 shown above is that there is a significant negative relationship between complexity of the tax system and income tax compliance $\left(r=-.255^{* *}, \mathrm{p}<0.01\right)$. Therefore, the more the complexity of the tax system is, the less compliant the income tax will be. For instance, if there are loopholes in the tax system; the legislation and administrative procedures of income tax is not simple; and the tax system is not well designed and not easy to understand (such as rate of tax, filing and paying dates), they are not bound to pay their actual tax 
amount assessed and will not be paid on time, and consequently they are forced to evasion and avoidance of taxation.

\subsection{Regression Assumption Checks}

Before testing the hypothesis, the regression assumption of multi co linearity is checked. One method to detect high multi co linearity is variance-inflating factor (VIF).

Table 4.6: multi collinearity between independent variables

\begin{tabular}{l|l|l} 
Variables & Co linearity Statistics \\
\cline { 2 - 3 } & Tolerance & VIF \\
\hline Perceptions of equity or fairness & .914 & 1.094 \\
\hline Organizational strength of tax authority & .968 & 1.033 \\
\hline Appropriate Enforcement of tax Law & .953 & 1.049 \\
\hline Tax knowledge & .948 & 1.055 \\
\hline Tax rate & .945 & 1.058 \\
\hline Complexity of the tax system & .952 & 1.050 \\
\hline
\end{tabular}

Source: SPSS result based on primary data (2019)

According to this study the VIF is found to be less than 1.094 . Hence, multi co linearity is not a cause for concern. Meaning, there is no multi co linearity between the independent variables.

\subsection{Regression Analysis}

A regression was run to determine the predictive power of the independent variables (perceptions of equity/fairness, strength of tax authority, lack of ability to pay, enforcement of tax law, tax knowledge, tax rate and complexity of tax system) in explaining income tax compliance of taxpayers in EMR Bahir Dar branch. The results are thus presented in table 4.7 .

Table 4.7: Regression model of independent variables and dependent variable Coefficients $^{\mathrm{a}}$

\begin{tabular}{|c|c|c|c|c|c|}
\hline \multirow[t]{2}{*}{ Model } & \multicolumn{2}{|c|}{$\begin{array}{l}\text { Unstandardized } \\
\text { Coefficients }\end{array}$} & \multirow{2}{*}{\begin{tabular}{|l|}
$\begin{array}{l}\text { Standardized } \\
\text { Coefficients }\end{array}$ \\
Beta \\
\end{tabular}} & \multirow[t]{2}{*}{$\mathrm{T}$} & \multirow[t]{2}{*}{ Sig. } \\
\hline & $\mathrm{B}$ & Std. Error & & & \\
\hline 1 (Constant) & .948 & .447 & & 2.121 & $.036^{*}$ \\
\hline Perceptions of equity or fairness & .253 & .068 & .286 & 3.715 & $.000 * *$ \\
\hline Organizational strength of tax authorities & .192 & .065 & .223 & 2.978 & $.004 * *$ \\
\hline Lack of ability to pay & -.140 & .050 & -.211 & -2.793 & $.006^{* *}$ \\
\hline 1 Appropriate Enforcement of tax law & .242 & .080 & .230 & 3.035 & $.003 * *$ \\
\hline Tax knowledge & .243 & .049 & .377 & 4.971 & $.000 * *$ \\
\hline Tax rate & -.142 & .056 & -.194 & -2.528 & $.013^{*}$ \\
\hline Complexity of the tax system & -.183 & .068 & -.203 & -2.689 & $.008 * *$ \\
\hline
\end{tabular}

$\mathrm{R}=.634^{\mathrm{a}}, \mathrm{R}$ Squared $=.402$, Adjusted R Squared $=.364, \mathrm{Sig}=.000 \mathrm{a}$,

F Change 10.574 (p-value $=0.000)$

a. Dependent Variable: Income tax compliance

Note:-* Significant at the 0.05 level.

** Significant at the 0.01 level

Source: SPSS result based on primary data (2019)

From the above table, it can be formulated as:

$\mathrm{ITCi}=+\beta 1 \mathrm{PE} \mathrm{i}+\beta 2 \mathrm{STAi}+\beta 3 \mathrm{LAPi}+\beta 4 \mathrm{ETLi}+\beta 5 \mathrm{TKi}+\beta 7 \mathrm{TRi}+\beta 8 \mathrm{CTSi}+\mathrm{ei}$

$\mathrm{ITCi}=0.948+0.253 \mathrm{PEi}+0.192 \mathrm{STAi}-0.140 \mathrm{LAPi}+0.242 \mathrm{ETLi}+0.243 \mathrm{TKi}-0.142 \mathrm{TRi}-0.183 \mathrm{CTSi}$

The predictive power of the model is shown by R Square. R-Square ranges between 0 and 1 , with values over 0.4 indicating a good fit between the predictions and actual data. Typically, values of $\mathrm{R}$ squared below 0.2 are considered weak, between 0.2 and 0.4, moderate, and above 0.4, strong (SPSS Regression manual, 2010).

The regression results on the above table 4.7 revealed that independent variables (perceptions of equity/fairness, strength of tax authority, lack of ability to pay, enforcement of tax law, tax knowledge, tax rate and complexity of tax system) explain $40.2 \%$ of the variation in income tax compliance, indicating a good fit since it is above $40 \%$. All the predictors were observed to be more significant predictors of income tax 
compliance at sig $<0.05$ and sig $<0.01$. The regression model by itself is statistically significant at the $5 \%$ level $(\mathrm{F}$-value $=10.574, \mathrm{p}<0.000)$.

To test the hypotheses of the multiple regression analysis we use the general guideline:

$>$ (If $S E\left(\hat{\beta}_{1}\right)>1 / 2 \hat{\beta}_{1}$, we accept the null hypothesis that is, we can conclude that the estimate $\beta_{i}$ is not statistically significant.

$>$ If $S E\left(\hat{\beta}_{1}\right)<1 / 2 \hat{\beta}_{1}$, we reject the null hypothesis that is, we can conclude that the estimate $\beta_{i}$ is statistically significant. Note that beta is at absolute value.

Having this at $\mathrm{p}$ value $\mathrm{p}=0.000^{* *}$ and Beta coefficient of $(0.253)$, the multiple regression analysis revealed that: $0.068<(0.253 / 2), 0.068<0.126$

Therefore, we reject the null hypothesis $\mathrm{H} 1$ that is; the perception of equity or fairness has significant effect on income tax compliance. The hypothesis (H1) states that holding other independent variables constant, perception of equity or fairness has influence on the income tax compliance. The result suggests that an increase of a $1 \%$ in the perception of equity will increase the rate of income tax compliance by $0.25 \%$. The results of this study are similar with the Lemessa T. (2007) found that perceptions of equity or fairness do influence compliance behavior using their analytical analysis.

From table 4.7, it is clear that the organizational strength of tax authorities has significant effect on income tax compliance. This can be checked at $\mathrm{p}$ value $(\mathrm{p}<0.01)$ and Beta coefficient of $(0.192)$, the multiple regression analysis revealed that: $0.065<(0.192 / 2), 0.065<0.096$

Therefore, we reject the null hypothesis $\mathrm{H} 2$ that is organizational strength of tax authority has significant effect on income tax compliance. The hypothesis $(\mathrm{H} 2)$ states that holding other independent variables constant, organizational strength of tax authority has influence on the income tax compliance. The result suggests that an increase of a $1 \%$ in the organizational strength will increase the rate of income tax compliance by $0.19 \%$. Therefore, we can generalize that there is a direct significant and positive relationship between organizational strength of tax authority and income tax compliance.

At $\mathrm{p}$ value $(\mathrm{p}<0.01)$ and Beta coefficient of $(-0.140)$ of financial constraints, the multiple regression analysis revealed that: $0.050<(-0.140 / 2), 0.050<0.07$

Therefore, we reject the null hypothesis $\mathrm{H} 3$ that is; the financial constraint has significant effect on income tax compliance. The results revealed that holding other independent variables constant, financial constraint has more influence on the income tax compliance. The results of this study also show that financial constraint (lack of ability to pay) did not exert a positive effect on income tax compliance, rather has a negative and significant effect on income tax compliance. Generally, a loss-making company or taxpayers with a strong financial constrain tend to engage in noncompliance. For instance, an increase in a $1 \%$ in financial constraint will decrease the rate of income tax compliance by $0.14 \%$. The results of this study are similar with Mohd R. P. (2010) who found that lack of ability to pay does influence compliance behavior significantly and negatively using regression analysis.

From table 4.7, it is clear that the appropriate enforcement of tax law has significant effect on income tax compliance. This can be checked at $\mathrm{p}$ value $(\mathrm{p}<0.01)$ and Beta coefficient of $(0.242)$, the multiple regression analysis revealed that: $0.080<(0.242 / 2), 0.080<0.121$

Therefore, we reject the null hypothesis H4 that is; appropriate enforcement of tax law has significant effect on income tax compliance. The hypothesis (H4) states that holding other independent variables constant, appropriate enforcement of tax law has influence on the income tax compliance. The result suggests that an increase of a $1 \%$ in the appropriate enforcement of tax law will increase the rate of income tax compliance by $0.24 \%$. These findings are similar with a previous study by Gloria M. (2011) which revealed a positive and significant relationship between enforcement of tax law and income tax compliance.

In the same table, it is clear that tax knowledge has significant effect on income tax compliance. At $\mathrm{p}$ value $\mathrm{p}=0.000^{*}$ and Beta coefficient of (0.243) tax knowledge, the multiple regression analysis revealed that: $0.049<$ $(0.243 / 2), 0.049<0.121$

Therefore, we reject the null hypothesis H5 that is the level of tax knowledge has significant effect on income tax compliance. The results revealed that holding other independent variables constant, the level of tax knowledge has more influence on the income tax compliance. Therefore we can generalize that there is a direct significant and positive relationship between tax knowledge and income tax compliance. The result suggests that an increase of a $1 \%$ in the tax knowledge will increase the rate of income tax compliance by $0.24 \%$. The results of this study are similar with Annet N. (2010), and Mohd R. P. (2010) who found that tax knowledge does influence compliance behavior significantly and positively.

At $p$ value $(p<0.05)$ and Beta coefficient of $(-0.142)$ of tax rate, the multiple regression analysis revealed that: $0.056</(-0.194 / 2) /, 0.056<0.071$

Therefore, we reject the null hypothesis H6 that is; the tax rate has significant effect on income tax compliance. The results revealed that holding other independent variables constant, tax rate has more influence 
on the income tax compliance. The results of this study also show that tax rate did not exert a positive effect on income tax compliance; rather it has a negative and significant effect on income tax compliance. Therefore, as far as the tax rate increases, the taxpayers' compliance nature of income tax would be decreases. For instance, an increase in a $1 \%$ in tax rate will decrease the rate of income tax compliance by $0.14 \%$.

At $p$ value $p=0.000^{*}$ and Beta coefficient of $(-0.183)$ of complexity of the tax system, the multiple regression analysis revealed that: $0.068</(-0.183 / 2) /, 0.068<00915$

Therefore, we reject the null hypothesis H7 that is; the complexity the tax system has significant effect on income tax compliance. The results revealed that holding other independent variables constant, complexity the tax system has more influence on the income tax compliance. For instance, an increase in a $1 \%$ in complexity of tax system will decrease the rate of income tax compliance by $0.18 \%$. The results of this study also show that complexity the tax system did not exert a positive effect on income tax compliance; rather it has a negative and significant effect on income tax compliance.

\section{Conclusions and Recommendations}

\subsection{Conclusions}

The Seven basic hypotheses were developed and then tested using correlation and regression analysis. The correlation result shown in table 4.5 is that except for tax rate are all independent variables are more significant, those are perceptions of equity/fairness $\left(\mathrm{r}=.229^{*}, \mathrm{p}=<0.05\right)$, organizational strength of tax authority $\left(\mathrm{r}=.222^{*}\right.$, $\mathrm{p}<0.05)$, appropriate enforcement of tax law $\left(\mathrm{r}=.214^{*}, \mathrm{p}<0.05\right)$, and tax knowledge $\left(\mathrm{r}=.313^{* *}, \mathrm{p}<0.01\right)$ positively related with income tax compliance while lack of ability to pay $\left(\mathrm{r}=-.217^{*}, \mathrm{p}<0.05\right)$, and complexity of the tax system $\left(r=-.225^{* *}, \mathrm{p}<0.01\right)$ are significant but negatively related with income tax compliance. The positive relationship means as the independent variables increases, taxpayers are more compliant to income tax. While, if there is a negative relationship between them an increase in the independent variables would cause a decrease in income tax compliance.

The regression results of table 4.7 revealed that the aforementioned independent variables explain $40.2 \%$ of the variation in income tax compliance, indicating a strong fit since it is above $40 \%$. This implies that other factors not in the current study accounted for the remaining $59.8 \%$ of variance in income tax Compliance. All the predictors were observed to be more significant predictors of income tax compliance at sig $<0.05$ and sig $<$ 0.01 . The regression model by itself is statistically significant at the $5 \%$ level $(\mathrm{F}$-value $=10.574, \mathrm{p}<0.000)$.

\subsection{Recommendations}

The most obvious requirement for fairness or equity is to treat equal people in equal circumstances in an equal way. In other words, it is unfair to say that the tax system is equitable as long as several capable traders are not paying tax. Taxpayers will be discouraged to the extent that the tax is believed to be unfair and inequitable or so many others are not paying. Generally, the authority has to try its level best in ensuring tax fairness and equity so that voluntary compliance behavior can be developed.

The tax authority needs to be implementing the tax law effectively and efficiently. Functions such as tax assessment, collection, awareness creation, and providing training has to be performed effectively and efficiently, to create an efficient tax administration, the tax authority needs to strengthen itself by educating and training its employees, by computerizing its operations, devoting additional resources.

There should be proper enforcement of the tax law in place through penalizing noncompliant taxpayers and detecting noncompliant tax payers through an audit and just by increasing penalty rates, this will promote tax compliance.

The tax payers need to improve on tax competencies or knowledge. This could be done through intensive tax education by EMR, by electronic communication distribute tax proclamation, rules \& regulations for tax payers to update tax knowledge's. This will enable them comply with their tax requirements.

The Government shall minimize or adjust a tax rate so as to increase compliance behavior of tax payers and also increase tax revenue and reduce tax evasion \& avoidance.

A tax system should be simplified because in most cases they are found to be very complicated for taxpayers, and also not understand the tax laws easily in order to reduce the compliance costs in terms of money and time.

\section{References}

Annet Nakiwala (2010). tax competencies, compliance costs and income tax compliance among SMEs in Uganda, Makerere University.

Eckstein, Otto. (1979). Public Finance 4th edition. Englewood Cliffs, USA: Prentice- Hall, INC.

Gloria Mesiku (2011). tax administration, procedural justice, tax payers' attitude and tax compliance among small business income earners in Arua District, Makerere University.

IMF. (2010). International Tax Dialogue Revenue Administration in Sub-Saharan Africa, ITD Comparative 
Information Series No 1. 2010, www.itdweb.org

James, S. and Nobes, C. (2000). The Economics of Taxation: Principles, Policy and Practice 7th edition. Prentice-Hall.

James, S., and Alley, C. (2004). Tax Compliance, self-assessment and tax administration. Journal of Finance and Management in Public Services.

Kirchler, E. (2007). The Economic Psychology of Tax Behavior. Cambridge: Cambridge University Press.

Lemessa Tulu (2007). A research project on determinants of taxpayers' Voluntary compliance with taxation, the case study of Dire Dawa City, Addis Ababa university School of graduate studies, Addis Ababa

Loo, E.C. (2006). The influence of the introduction on self-assessment on compliance behavior of individual taxpayers in Malaysia. $\mathrm{PhD}$ thesis. University of Sydney.

Lymer, A., and Oats, L. (2009). Taxation: Policy and Practice. 16th ed. Birmingham: Fiscal Publications.

Mohd Rizal Palil (2010). Tax knowledge and tax compliance determinants in self-assessment system in Malaysia, a thesis submitted to the University of Birmingham for the degree of doctor of philosophy department of accounting and finance Birmingham Business School.

Negarit Gazette, (2002). Income tax proclamation 286/2002, EFDR: Ethiopia,

Organization for Economic Cooperation and Developmnt. (2001). Compliance measurement- Practice note. Paris: Central for Tax Policy and Administration.

Silvani, C. A. (1992). Improving tax compliance. In M. B. Richard, Improving tax administration in developing countries,(eds). Washington D. C.: IMF.

Soos, P. (1991). Self-employed evasion and tax withholding: A comparative study and analysis of the issues. Working paper, University of California.

SPSS Regression (2010). Center for teaching, research \& learning: social Science Lab America University, Washington ,D.C.

Zelalem B., (2011). The influence of tax education on tax compliance attitude, Addis Ababa, Ethiopia 